\title{
Describing vancomycin serum levels in pediatric intensive care unit (ICU) patients: are expected goals being met
}

\author{
Talita Muniz Maloni $i^{*}$, Talita Rantin Belucci ${ }^{1,2}$ (D) Sandra Regina Malagutti ${ }^{3}$ and Guilherme Henrique Campos Furtado ${ }^{4}$
}

\begin{abstract}
Background: In the pediatric population, infections by methicillin-resistant Staphylococcus aureus (MRSA) are associated with significant morbidity and hospital costs. Vancomycin is a glycopeptide antibiotic, widely used for the treatment of serious infections by Gram-positive microorganisms, especially MRSA. It is recommended to keep the serum level of vancomycin between 10 and $20 \mathrm{mg} / \mathrm{L}$, that correlates with AUC/MIC > 400 in adults. This pharmacodynamic target is extrapolated to pediatric patients despite the lack of similar evidence. However, recent studies suggest that serum levels between 7 and $10 \mathrm{mg} / \mathrm{L}$ are predictive of reaching the pharmacodynamic target in this population. In spite of widespread use, ideal information about dosage for the pediatric population remains limited.

Methods: A retrospective study was conducted in patients admitted to the Pediatric Intensive Care Unit during the period between January 01, 2008 to December 31, 2014. We investigated variables such as age, positive fluid balance and use of vasoactive drugs on the ability of these patients to achieve the proposed recommended serum level target and the vancomycin serum levels.

Results: Our study showed that only $26 \%$ of children reached the $10-20 \mathrm{mg} / \mathrm{L}$ serum level whereas the $7-20 \mathrm{mg} / \mathrm{L}$ serum level was reached by $51 \%$ of patients.

Conclusions: We observed no evidence of a significant association between the inadequacy of serum level and age. The positive fluid balance also had no influence on the vancomycin serum level but patients using vasoactive drugs had a greater serum level adequacy than patients not using vasoactive drugs.
\end{abstract}

Keywords: Vancomycin serum level, Pediatrics, Pharmacokinetics, Pharmacodynamics

\section{Background}

Infections in intensive care units (ICU) are associated with high morbidity and mortality rates [1]. In the United States, infections caused by methicillin-resistant Staphylococcus aureus (MRSA) cause $8 \%$ of all hospitalacquired infections, and MRSA infections are associated with an estimated 18,650 deaths annually [2]. In the pediatric population, MRSA infections are also associated with significant morbidity and hospital expenses [3].

\footnotetext{
* Correspondence: talita.maloni@gmail.com

${ }^{1}$ Pharmacist Hospital Israelita Albert Einstein, Avenida Albert Einstein, 627

Morumbi, São Paulo, Brasil05651-901

Full list of author information is available at the end of the article
}

The appropriate treatment for severe infections caused by $S$. aureus represents a significant challenge as the therapeutic failure can result in death [1]. Vancomycin is a glycopeptide antibiotic widely used for the treatment of severe infections caused by Gram-positive microorganisms, especially MRSA. Currently, it is considered the first choice for empirical therapy of these infections $[4,5]$.

According to the consensus recommendations of the Infectious Diseases Society of America (IDSA), American Society of Health System Pharmacists and Society of Infectious Diseases Pharmacists, keeping the area under the curve (AUC)/minimum inhibitory concentration $(\mathrm{MIC})>400$ is a suitable target to achieve a successful outcome in the treatment of 
MRSA infections [6]. This pharmacodynamic target is considered the best predictor of microbiological and clinical outcomes when treating MRSA infections [7]. However, the calculation of the AUC is clinically impractical. Trough serum concentration measured shortly before the fourth dose, i.e. steady state, with a value of 15-20 $\mathrm{mg} / \mathrm{L}$, is correlated with an AUC/MIC $>400$ in adult patients with MRSA MIC $<1 \mathrm{mcg} / \mathrm{mL}$ [6].

These recommendations were made following a review of in vitro studies and animal and human studies. However, they were intended to be used for adult patients. These guidelines for vancomycin therapy and adjustment did not include recommendations for pediatric patients making use of vancomycin in pediatric patients a unique and specific challenge $[8,9]$.

Recent studies involving the pharmacokinetics and pharmacodynamics of vancomycin in pediatric patients suggest that the trough serum level of approximately $7-11 \mathrm{mg} / \mathrm{L}$ is sufficient to achieve an AUC/MIC > 400 in the pediatric population $[10,11]$.

The pediatric population shows differences in pharmacokinetic parameters in relation to adults and therefore requires individualized and specific doses [12]. Besides, the physiological changes in the percentage of body water and renal clearance can also alter pharmacokinetic parameters such as volume of distribution $(\mathrm{Vd})$ and elimination half-life, which can lead to lower than recommended serum levels [13]. Despite the extensive use of vancomycin, dosage information to optimize therapy needs to be further explored [14]. Low concentrations of vancomycin can result in less effective therapy and increased propensity for bacterial resistance due to the risk of not reaching AUC/MIC > 400 [5].

The goal of this study is to evaluate the results of a protocol of vancomycin utilization in a pediatric Intensive Care Unit (PICU). We analyzed the serum levels determining the frequency of children with target serum levels between 10 and $20 \mathrm{mg} / \mathrm{L}$. In addition, we investigated the influence of age, positive water balance and use of vasoactive drugs on the ability of these patients to achieve a target serum level between 10 and $20 \mathrm{mg} / \mathrm{L}$.

\section{Methods}

This study was conducted in a tertiary care, private hospital in São Paulo, Brazil with 629 beds and approximately 194,000 patient-days yearly and approved by the Institutional Review Board and Ethics Committee of Hospital Israelita Albert Einstein and informed consent was not required.

A retrospective study was conducted from January 01, 2008 to December 31, 2014 in the PICU.

This study describes if inpatients who received vancomycin and had at least one serum trough vancomycin measure. Trough concentrations were defined as values taken within $1 \mathrm{~h}$ of the next due dose. The hospital guidelines stipulate that the first trough concentration be measured before the fourth dose. The recommended of all target serum level of vancomycin according to the hospital guidelines is 10 to $20 \mathrm{mg} / \mathrm{L}$.

The data abstracted from the electronic medical record included demographics and clinical data, vancomycin dose and alterations during the entire treatment, duration of treatment, presence of positive fluid balance (water balance), use of vasoactive drugs (dobutamine, dopamine, epinephrine, norepinephrine) on the day of vancomycin serum level collection, etiologic agents isolated in cultures, trough vancomycin levels and outcome status (death was defined as in-hospital mortality). The study included patients older than 28 days and younger than 19 years with a creatinine clearance $(\mathrm{ClCr})$ greater than $50 \mathrm{~mL} / \mathrm{min}$ who had used vancomycin for over 48 h. Patients excluded were newborns patients (post-natal age equal to or less than 28 days old), patients aged 19 years or older, patients treated with vancomycin less than $48 \mathrm{~h}$ and patients with a $\mathrm{ClCr}$ equal to or less than $50 \mathrm{~mL} / \mathrm{min}$ during treatment with vancomycin.

\section{Statistical analysis}

The categorical variables were described by absolute and relative frequencies (percentages) and quantitative variables by summary measures as the mean and standard deviation (SD) or median and quartiles, along with minimum and maximum value. For the analysis of possible factors associated with inadequate serum levels, generalized linear models were adjusted with mixed effects in which the identification of the child, of the passage and collection were included in the model as random effects to consider the dependency among this information [15]. Analyses were performed using the SPSS and R programs with the lme4 package $[16,17]$.

\section{Results}

In the period of study, there were 1899 hospitalizations in the PICU and vancomycin doses were administered to 184 patients $(9.7 \%)$. Seventy-four patients were not included in the analysis. Thus, we analyzed 110 patients who used vancomycin in the PICU.

In the period of study, 217 collections were performed in 96 of the 110 patients analyzed (87.3\%), showing that in $14(12.7 \%)$ of them, no vancomycin trough level was collected. For those patients with serum vancomycin levels, 40 (41.7\%) reached a therapeutic level (between 10 and $20 \mathrm{mcg} / \mathrm{mL}$ ) in at least one collection and 56 (58.3\%) did not reach those levels in any collection. The time to reach the therapeutic level from the first dose administered ranged from 0.5 to 17.9 days, with a mean of 2.9 days (IQR: 1.9, 5.3 days). 
Table 1 shows the descriptive analysis of inpatient characteristics at the time of hospitalization.

The PIM II (pediatric index of mortality II) of patients ranged between 0.1 and 27.5, with a median of 1.8 (first quartile 1.0 and third quartile 5.1).

The major diagnoses that appeared most frequently were respiratory failure in $30.0 \%$ of patients followed by major post-op surgery in $20.9 \%$ of patients.

Most of the patients presented underlying conditions (71.8\%), with neurological diseases being most frequent (25.5\%). Some patients had more than one underlying conditions: two patients had heart disease and neurological disease, two with respiratory failure and neurological disease, two with neurological and endocrine/ metabolic diseases and one with neurological disease and cancer.

In the sample studied, $48.2 \%(n=53)$ of the patients had a positive microbiologic culture. The patients had between one and five agents identified. Staphylococcus aureus was the most frequent agent followed by Staphylococcus epidermidis (Table 2).

The number of samples taken for evaluation of vancomycin trough serum levels varied between 0 and 11, being undertaken in $87.3 \%$ of the 110 patients evaluated.

The average duration of vancomycin treatment was 8.7 days (first quartile: 4.3 days and third quartile: 13.0 days). Seven patients died during hospitalization representing $6.4 \%$ of the sample of 110 patients. The trough levels related to this mortality rate ranged from $<5$ to $17.3 \mathrm{mg} / \mathrm{L}$.

The information about the interval between dose administration and vancomycin serum collection, time between the collection and the next dose and time of collection are described in Table 3.

The median of the initial dose was $40 \mathrm{mg} / \mathrm{kg} /$ day, ranging from 30 to $84 \mathrm{mg} / \mathrm{kg} /$ day. In relation to all doses administered during treatment with vancomycin, the

Table 1 Characteristics of inpatients $(N=110)$

\begin{tabular}{ll}
\hline Age (years) $-\mathrm{n}(\%)$ & \\
\hline Median (IQR) & $4.1(1.2 ; 10.8)$ \\
\hline Age Classification - $\mathrm{n}(\%)$ & $43(39.1 \%)$ \\
$\quad$ <2 years & $23(20.9 \%)$ \\
2-6.9 years & $25(22.7 \%)$ \\
7-12.9 years & $19(17.3 \%)$ \\
13-18 years & \\
Weight $(\mathrm{kg})-\mathrm{n}(\%)$ & $16(9 ; 35)$ \\
$\quad$ Median (IQR) & \\
Gender - $\mathrm{n}(\%)$ & $59(53.6 \%)$ \\
Female & $51(46.4 \%)$ \\
Male &
\end{tabular}

Table 2 Positive microbiologic cultures of vancomycin serum level collection $(N=110)$

\begin{tabular}{ll}
\hline Microbiologic culture $-\mathrm{n}(\%)$ & \\
\hline Negative & $57(51.8 \%)$ \\
\hline Positive & $53(48.2 \%)$ \\
Positive microbiologic culture ${ }^{\mathrm{a}}-\mathrm{n}(\%)$ & $12(10.9 \%)$ \\
Staphylococcus aureus & $9(8.2 \%)$ \\
Staphylococcus epidermidis & $8(7.3 \%)$ \\
Pseudomonas aeruginosa & $5(4.5 \%)$ \\
Escherichia coli & $4(3.6 \%)$ \\
Enterobacter cloacae & $4(3.6 \%)$ \\
Streptococcus pneumoniae & $2(1.8 \%)$ \\
Proteus mirabilis & $2(1.8 \%)$ \\
Serratia marcescens & $2(1.8 \%)$ \\
Staphylococcus haemolyticus & $12(10.9 \%)$ \\
Others &
\end{tabular}

${ }^{a}$ More than one positive organism for the same microbiologic culture

total daily dose of vancomycin varied from $24 \mathrm{mg} / \mathrm{kg} /$ day to $100 \mathrm{mg} / \mathrm{kg} /$ day, with a median of $40 \mathrm{mg} / \mathrm{kg} /$ day.

Table 4 shows the variation of vancomycin serum levels. The values of vancomycin serum levels varied between $<5$ and $31.4 \mathrm{mg} / \mathrm{L}$, with a median of $7.7 \mathrm{mg} / \mathrm{L}$ (first quartile $<5 \mathrm{mg} / \mathrm{L}$ and third quartile $10.6 \mathrm{mg} / \mathrm{L}$ ). The serum levels between 10 and $20 \mathrm{mg} / \mathrm{L}$ were reached in $26.3 \%$ of the collections and the serum levels between 7 and $20 \mathrm{mg} / \mathrm{L}$ were reached in $51.6 \%$ of the collections. Serum levels of less than $10 \mathrm{mg} / \mathrm{L}$ represented $69.1 \%$ of all collections.

Patients receiving dose of $\leq 40 \mathrm{mg} / \mathrm{kg} /$ day presented a serum level $<10 \mathrm{mg} / \mathrm{L}$ in $71.3 \%$ of the collections, with this same dosage the serum level between 10 and $14 \mathrm{mg} / \mathrm{L}$ was reached in only $18.6 \%$ of the collections.

Table 3 Interval between dose and vancomycin serum level collection, time between the collection and the next dose and time of collection for the initial treatment $(n=96)$ and all collections $(n=217)$

\begin{tabular}{|c|c|c|}
\hline & $\begin{array}{l}\text { First collection } \\
(n=96)\end{array}$ & $\begin{array}{l}\text { All the collections } \\
(n=217)\end{array}$ \\
\hline \multicolumn{3}{|c|}{ Interval between dose and the next collection (days) - n (\%) } \\
\hline Median (IQR) & $2.0(1.3 ; 3.3)$ & $2.1(1.4 ; 3.5)$ \\
\hline \multicolumn{3}{|c|}{ Time between the collection and the next dose (minutes) $-\mathrm{n}(\%)$} \\
\hline Median (IQR) & $30(15 ; 52.5)$ & $32(15 ; 48)$ \\
\hline \multicolumn{3}{|l|}{ Time of collection - n (\%) } \\
\hline $\begin{array}{l}\text { Trough (up to } 1 \mathrm{~h} \text { before the } \\
\text { next dose) }\end{array}$ & 79 (82.3\%) & $182(83.9 \%)$ \\
\hline $\begin{array}{l}\text { More than } 1 \mathrm{~h} \text { before the } \\
\text { next dose }\end{array}$ & $17(17.7 \%)$ & $35(16.1 \%)$ \\
\hline
\end{tabular}


Table 4 Variation of vancomycin serum level according to daily dose $(n=217)$

\begin{tabular}{|c|c|c|c|c|}
\hline \multirow{2}{*}{$\begin{array}{l}\text { Vancomycin serum levels } \\
(\mathrm{mg} / \mathrm{L})-\mathrm{n}(\%)\end{array}$} & \multicolumn{4}{|c|}{ Vancomycin: Daily dose (mg/kg/day) } \\
\hline & $\leq 40(n=129)$ & 41 to $50(n=26)$ & 51 to $60(n=35)$ & $\geq 61(n=27$ \\
\hline$\leq 5$ & $49(38,0 \%)$ & $7(26,9 \%)$ & $13(37,1 \%)$ & $3(11,1 \%)$ \\
\hline 6 to 9 & $43(33,3 \%)$ & $7(26,9 \%)$ & $14(40,0 \%)$ & $14(51,9 \%)$ \\
\hline 10 to 14 & $24(18,6 \%)$ & $6(23,1 \%)$ & $6(17,1 \%)$ & $6(22,2 \%)$ \\
\hline 15 to 20 & $8(6,2 \%)$ & $5(19,2 \%)$ & $2(5,7 \%)$ & $0(0,0 \%)$ \\
\hline$\geq 21$ & $5(3,9 \%)$ & $1(3,8 \%)$ & $0(0,0 \%)$ & $4(14,8 \%)$ \\
\hline
\end{tabular}

Of all vancomycin serum level collections performed $(\mathrm{n}=217)$, only 211 were possible to identify if the patients used vasoactive drugs at the time of vancomycin serum level collection. $89,6 \%(n=189)$ did not use vasoactive drugs and $10,4 \%(n=22)$ used vasoactive drugs.

Table 5 shows the results of the mixed logistic models that analyzed factors associated with inadequate serum levels of vancomycin. None variable is related to inadequate vancomycin levels. Otherwise, we found that patients using vasoactive drug had the odds of inadequate serum levels reduced by $73 \%$, compared to patients who did not use vasoactive drug.

\section{Discussion}

Monitoring of vancomycin serum levels is important both to keep track of the toxicity and effectiveness of the treatment. In adults, AUC/MIC $>400$ of vancomycin is associated with better clinical and bacteriological response in patients with MRSA infections, and this target is extended to pediatric patients, despite the lack of similar evidence [18]. Although the AUC/MIC >400 pharmacodynamic parameter is ideal to determine the clinical efficacy of vancomycin, serum concentration can be used as it is a more practical method [19, 20].

Tkachuk $\mathrm{S}$ et al, showed that vancomycin target serum levels varied based on the characteristics of the patient, however, for pediatric patients, in general, levels between 6 and $10 \mathrm{mg} / \mathrm{L}$ are sufficient to achieve AUC/MIC $\geq 400$ [18]. Frymoyeret al, suggest that trough serum levels of $15-20 \mathrm{mg} / \mathrm{L}$ are unnecessary to attain AUC/MIC $>400$ in the pediatric population, as minimal concentrations of

Table 5 Mixed logistical models of serum level inadequacy

\begin{tabular}{llll}
\hline & Odds ratio & IC 95\% & $P$ value \\
\hline Age (years) & 0.96 & $(0.89-1.03)$ & 0.242 \\
Age < 2 years & 1.00 & & \\
Age 2-6.9 years & 2.12 & $(0.81-5.58)$ & 0.127 \\
Age 7-12.9 years & 0.51 & $(0.21-1.23)$ & 0.132 \\
Age 13-18 years & 0.95 & $(0.32-2.86)$ & 0.926 \\
WB positive: Yes & 0.94 & $(0.45-1.95)$ & 0.862 \\
Use of VAD: Yes & 0.23 & $(0.08-0.64)$ & 0.005 \\
\hline
\end{tabular}

Cl 95\% 95\% confidence interval for the odds ratios, WB water balance, VAD Vasoactive drugs vancomycin between 7 and $10 \mathrm{mg} / \mathrm{L}$ were predictive of reaching the pharmacodynamic target of AUC/MIC $>400$ in approximately $90 \%$ of the simulations carried out with children receiving the dose of $15 \mathrm{mg} / \mathrm{kg}$ every $6 \mathrm{~h}$ [10]. Our study showed that only $26 \%$ of the children reached a serum level of $10-20 \mathrm{mg} / \mathrm{L}$.

Adult guidelines suggest that AUC/MIC $>400$ corresponds to a vancomycin serum concentration of 15 to $20 \mathrm{mg} / \mathrm{L}$ for treating MRSA infections, however, children rarely reach this serum level. The study conducted by Kishk et al., found that the correlation of the AUC/MIC $>400$ was associated with the average concentration of $11.4 \mathrm{mg} / \mathrm{L}$. [11] In our study, we performed the stratification to assess the distribution of vancomycin serum level with values achieved between 7 and $14 \mathrm{mg} / \mathrm{L}$. We observed that $44.7 \%$ of patients receiving vancomycin presented serum levels within this therapeutic range.

Considering the Kishik study, there is a greater number of patients in our study who attained a serum level related to the AUC/MIC > 400 target, with $7-14 \mathrm{mg} / \mathrm{L}$ result compared to the $15-20 \mathrm{mg} / \mathrm{L}$ serum level. In our study this level was only reached by $6.2 \%$ of patients. As this pharmacodynamic parameter best predicts the result in treating invasive infections and the calculation of the AUC is not practical from a clinical standpoint, the common practice is the assessment of vancomycin serum concentrations to monitor the adequacy of the dosage.

The pharmacokinetics of vancomycin differ in pediatric patients and studies in children confirm that few patients reach a trough serum level in the range of $15-20 \mathrm{mg} / \mathrm{L}$ when using the current recommended doses [11].

In 2009, Frymoyer et al. found that is unlikely that a vancomycin dose of $40 \mathrm{mg} / \mathrm{kg} / \mathrm{day}$ in children can reach the recommended pharmacodynamic target of AUC/MIC > 400 for invasive infections by MRSA, even when the MIC is $1 \mathrm{mcg} / \mathrm{mL}$ [8]. In our study, the average initial dose of $40 \mathrm{mg} / \mathrm{kg} /$ day proved to be insufficient to achieve the serum level of $10-20 \mathrm{mg} / \mathrm{L}$, for most patients emphasizing the need for a review of the available literature regarding the dose that offers the best pharmacokinetic and pharmacodynamic efficacy. 
We observed no evidence of a significant association between serum level adequacy $(10-20 \mathrm{mg} / \mathrm{L})$ and age. A previous study, which evaluated pharmacokinetic and pharmacodynamic parameters of vancomycin in critically ill children also did not demonstrate the influence of age on the parameters evaluated [13]. However, Gordon et al, found significant lower levels of vancomycin in children under the age of six, even using similar doses as those administered to older patients [21]. Madigan et al observed the effect of age and weight on serum concentrations of vancomycin in pediatric patients. The authors suggest for vancomycin's prescription in pediatric patients should also consider age and weight. The age classification for our study was based in the Madigan et al. study [22].

Another study that evaluated the influence of weight and age in vancomycin serum levels in children also showed that patients aged between two and five years presented initial serum levels below those proposed [2]. The fact that newborns, infants, children and adolescents present distinct physiological development could justify the association between age and lower serum levels. However, due to the pharmacokinetic variability in pediatric patients it is not possible to claim that the effects of maturity on the disposition of drugs are consistent within each age group [12].

In our study, we classified the age groups as $<2$ years, 2-6 years, $7-12$ years and $13-18$ years to assess whether the inadequacy of serum levels was specific of any age group. However, none of the age group showed to be related to inadequate serum levels. In previous studies, the relationship of serum levels according to age led to the dosage recommendations based on the age of the child. Hoang et al., suggest that for patients from one to five months to 13 to 18 years of age, a dose of $60 \mathrm{mg} / \mathrm{kg}$ per day would be appropriate for achieving target levels. For patients aged 6 months to 12 years of age, a dose of $70 \mathrm{mg} / \mathrm{kg} /$ day would be appropriate [23]. McCabe et al., suggest that in order to achieve a vancomycin serum level above $10 \mathrm{mg} / \mathrm{L}$, the dose for pediatric patients should be according to the age group: 1 month to 2 years: $95 \mathrm{mg} / \mathrm{kg} /$ day, $2-12$ years: $88 \mathrm{mg} / \mathrm{kg} /$ day and $12-$ 18 years: $75 \mathrm{mg} / \mathrm{kg} /$ day [24]. Le et al., showed that reaching the AUC/MIC $\geq 400$ target showed a variation according to age, and on that basis, the vancomycin dose of $60 \mathrm{mg} / \mathrm{kg} /$ day was ideal for individuals $\geq 12$ years and $70 \mathrm{mg} / \mathrm{kg} /$ day for those $<12$ years of age [14].

Two important factors that can hinder the serum concentration of antimicrobials are related to the increased volume of distribution and increased renal clearance caused by the intravenous administration of fluids and vasoactive drugs. Often, multiple conditions that can influence the pharmacokinetics are present at the same time, thus excessively complicating the prediction of adequate serum concentrations. In general, the conditions that led to a suboptimal dosage are prevalent. The volume of distribution describes the relationship between the dose and the resulting serum concentration but in conditions where $\mathrm{Vd}$ is increased, a reduction in the drug's serum level concentration is expected [25].

In our study, the positive fluid balance did not show any influence on vancomycin serum levels. In critically ill patients, alterations in physiopathologic conditions that leads to increased capillary permeability, formation of edema, vasodilation and hypotension may result in pharmacokinetics alterations in many antibiotics [26]. Also, the measures taken to reverse this situation such as the administration of large amounts of fluids, make it difficult to interpret the concentrations of vancomycin, the volume of distribution and, subsequently the degree of distribution throughout the tissue [27, 28]. As vancomycin is an antibiotic with a hydrophilic quality, the volume of distribution of vancomycin may be high, while plasma concentrations may be reduce [26]. Katip et al., evaluated pharmacokinetic aspects of vancomycin in patients in the early stage of septic shock and verified that the clearance of vancomycin increased while the volume of distribution did not increase [26]. Once the serum concentration prediction remains difficult in these situations the therapeutic drug monitoring for individual fine tuning of antimicrobial therapy seems most adequate [25].

Only the use of vasoactive drugs (VAD) proved to be a protective factor, since for patients using VAD, the chance of inadequacy of serum levels was $73 \%$ lower than patients who did not use VAD. These results are the opposite to what was expected since the use of VAD could modify renal blood flow and glomerular filtration increasing the rates of renal tubular secretion and clearance and, consequently, the elimination of hydrophilic drugs. Future studies are needed to confirm this finding [29].

It is important to note that this study was limited to a single hospital, involving a heterogeneous population of pediatric patients. However, as demonstrated, the administration of vancomycin as well as the monitoring of its use was in agreement with the recommended protocols.

Our results may be useful in the management of the vancomycin dose for pediatric patients guided by serum levels taking into account the frequency of children who reach the target between 10 and $20 \mathrm{mg} / \mathrm{L}$. The study of the relationship between the prescribed dose and serum level attained can contribute to the customization of treatment and monitoring of vancomycin therapy in children, increasing patient safety for a more effective therapy and lower risk of toxicity.

The serum level of $10-20 \mathrm{mg} / \mathrm{L}$ is hard to obtain in practice and certain clinical situations may warrant 
acceptance of lower targets that are more often obtained with current recommended doses.

Our study had some limitations as a single center retrospective study. Namely we could not identify the reason for instituting Vancomycin treatment. Further we did not evaluate efficacy or safety of the treatment including nephrotoxicity and adverse reactions.

\section{Conclusion}

The vancomycin serum level of $10-20 \mathrm{mcg} / \mathrm{mL}$ was not achieved by most of patients as compared to the therapeutic range of $7-20 \mathrm{mcg} / \mathrm{mL}$ that was achieved most frequently. According to the severity and location of the infection, the agent involved and the minimum inhibitory concentration of the pathogen, the $7-20 \mathrm{mcg} / \mathrm{mL}$ target might be enough for a microbiological and clinical efficacy.

\begin{abstract}
Abbreviations
AUC: Area under the curve; $\mathrm{CICr}$ : Creatine clearance; ICU: Intensive care units; IDSA: Infectious Diseases Society of America; MIC: Minimum inhibitory concentration; MRSA: Methicillin-resistant Staphylococcus aureus; PICU: Pediatric intensive care unit; PIM II: Pediatric index of mortality II; VAD: Vasoactive drugs; Vd: Volume of distribution; WB: Water balance
\end{abstract}

\section{Acknowledgements}

We gratefully acknowledge the healthcare workers that cared for pediatric patients at Hospital Israelita Albert Einstein, São Paulo, Brazil.

\section{Author's contributions}

TMM, TRB participated in the data collected. TMM, TRB, SRM, GCF participated in the data analysis. TMM, TRB, SRM, GCF participated in the design and coordination. TMM, TRB, SRM, GCF helped to draft the manuscript and to provide critical review to the manuscript. All authors read and approved the final manuscript.

\section{Funding}

No funding was obtained for this study.

\section{Availability of data and materials}

Confidentially agreements prevent us from sharing the raw data generated during this study. The data available upon request. The corresponding author should be contacted if someone wants to request the data.

\section{Ethics approval and consent to participate}

This study was approved by the Ethics Committee of the Instituto Israelita de Pesquisa Albert Einstein. The requirements for informed consent were waived by our IRB in accordance of the Code of Federal Regulation and of the Privacy Rule.

\section{Consent for publication}

Not applicable.

\section{Competing interests}

The authors declare that they have no competing interests. This research received no specific grant from any funding agency in the public, commercial, or non-for-profit sectors.

\section{Author details}

'Pharmacist Hospital Israelita Albert Einstein, Avenida Albert Einstein, 627 Morumbi, São Paulo, Brasil05651-901. ²Division of Medical Practice, Hospital Israelita Albert Einstein, São Paulo, Brazil. ${ }^{3}$ Statistics Department, Instituto Israelita de Ensino e Pesquisa Albert Einstein, Hospital Israelita Albert Einstein, São Paulo, Brazil. ${ }^{4}$ Division of Infectious Diseases, Escola Paulista de Medicina, Universidade Federal de São Paulo, São Paulo, Brazil.
Received: 18 January 2019 Accepted: 27 June 2019

Published online: 18 July 2019

\section{References}

1. Petrosillo N, Drapeau CM, Agrafiotis M, Falagas ME. Some current issues in the pharmacokinetics/pharmacodynamics of antimicrobials in intensive care. Minerva Anestesiol. 2010;76(7):509-24 Available from: https://www. minervamedica.it/en/getfreepdf/OhIWzyR\%252F3FEesM8\%252FWLkt\% 252BH\%252F4wNzF2DYgLyF3ePPMjsH2QXc3OPJ1HW6wdFZrs5NfA3Sjz WbFfULepL7QrsLOcg\%253D\%253D/R02Y2010N07A0509.pdf.

2. Milstone AM, Goldner BW, Ross T, Shepard JW, Carroll KC, Perl TM. Methicillin-resistant Staphylococcus aureus colonization and risk of subsequent infection in critically ill children: importance of preventing nosocomial methicillin-resistant Staphylococcus aureus transmission. Clin Infect Dis. 2011 Nov;53(9):853-9. https://doi.org/10.1093/cid/cir547.

3. Zervou FN, Zacharioudakis IM, Ziakas PD, Mylonakis E. MRSA colonization and risk of infection in the neonatal and pediatric ICU: a meta-analysis. Pediatrics. 2014 Apr;133(4):e1015-23. https://doi.org/10.1542/peds.2013-3413.

4. Estes KS, Derendorf H. Comparison of the pharmacokinetic properties of vancomycin, linezolid, tigecyclin, and daptomycin. Eur J Med Res. 2010;15:533-43

5. Marsot A, Boulamery A, Bruquerolle B, Simon N. Vancomycin: a review of population pharmacokinetic analyses. ClinPharmacokinet. 2012;51(1):1-13.

6. Rybak MJ, Lomaestro BM, Rotschafer JC, Moellering RC, Craig WA, Billeter M, Dalovisio JR, Levine DP. Vancomycin therapeutic guidelines: a summary of consensus recommendations from the infectious diseases Society of America, the American Society of Health-System Pharmacists, and the Society of Infectious Diseases Pharmacists. Clin Infect Dis. 2009;49(3):325-7. https://doi.org/10.1086/600877.

7. Moise-Broder PA, Forrest A, Birmingham MC, Schentag JJ. Pharmacodynamics of vancomycin and other antimicrobials in patients with Staphylococcus aureus lower respiratory tract infections. Clin Pharmacokinet. 2004;43(13):925-42. https://doi.org/10.2165/00003088200443130-00005

8. Frymoyer A, Hersh AL, Benet LZ, Guglielmo BJ. Current recommended dosing of vancomycin for children with invasive methicillin-resistant Staphylococcus aureus infections is inadequate. Pediatr Infect Dis J. 2009: 28(5):398-402. https://doi.org/10.1097/INF.0b013e3181906e40.

9. Eiland LS, English TM, Eiland EH 3rd. Assessment of vancomycin dosing and subsequent serum concentrations in pediatric patients. Ann Pharmacother 2011;45(5):582-589. doi: https://doi.org/10.1345/aph.1P588.

10. Frymoyer A, Guglielmo BJ, Hersh AL. Desired vancomycin trough serum concentration for treating invasive methicillin-resistant staphylococcal infections. Pediatr Infect Dis J. 2013;32(10):1077-9. https://doi.org/10.1097/ INF.0b013e318299f75c

11. Kishk OA, Lardieri AB, Heil EL, Morgan JA. Vancomycin AUC/MIC and Corresponding troughs in a pediatric population. J Pediatr Pharmacol Ther. 2017:22(1):41-7. https://doi.org/10.5863/1551-6776-22.1.41.

12. Bartelink IH, Rademaker CM, Schobben AF, van den Anker JN. Guidelines on paediatric dosing on the basis of developmental physiology and pharmacokinetic considerations. Clin Pharmacokinet. 2006;45(11):1077-97. https://doi.org/10.2165/00003088-200645110-00003.

13. Giachetto GA, Telechea HM, Speranza N, Oyarzun M, Nanni L, Menchaca A Vancomycin pharmacokinetic-pharmacodynamic parameters to optimize dosage administration in critically ill children. Pediatr Crit Care Med. 2011; 12(6):e250-4. https://doi.org/10.1097/PCC.0b013e3181fe4047.

14. Le J, Bradley JS, Murray W, Romanowski GL, Tran TT, Nguyen N, Cho S, Natale S, Bui I, Tran TM, Capparelli EV. Improved vancomycin dosing in children using area under the curve exposure. Pediatr Infect Dis J. 2013;32(4):e155-63. https://doi.org/10.1097/INF.0b013e318286378e.

15. McCulloch CE, Searle SR. Generalized, linear, and mixed models. New York. John Wiley and Sons Ltd.; 2005

16. SPSS Inc. SPSS statistics for windows [computer program]. Version 17.0. Chicago: SPSS Inc.; 2008

17. R Core Team. R: a language and environment for statistical computing [internet]. Vienna (AT): R Foundation for Statistical Computing; 2014. Available from: http://www.R-project.org/

18. Tkachuk S, Collins K, Ensom MHH. The relationship between vancomycin trough concentrations and AUC/MIC ratios in pediatric patients: a qualitative systematic review. Pediatr Drugs. 2018;20:153 https://doi.org/10. 1007/s40272-018-0282-4. 
19. Rybak M, Lomaestro B, Rotschafer JC, Moellering R Jr, Craig W, Billeter M, Dalovisio JR, Levine DP. Therapeutic monitoring of vancomycin in adult patients: a consensus review of the American Society of Health-System Pharmacists, the Infectious Diseases Society of America, and the Society of Infectious Diseases Pharmacists. Am J Health Syst Pharm. 2009;66(1):82-98. https://doi.org/10.2146/ajhp080434.

20. Liu C, Bayer A, Cosgrove SE, Daum RS, Fridkin SK, Gorwitz RJ, Kaplan SL, Karchmer AW, Levine DP, Murray BE, J. Rybak M, Talan DA, Chambers HF. Clinical practice guidelines by the infectious diseases society of america for the treatment of methicillin-resistant Staphylococcus aureus infections in adults and children: executive summary. Clin Infect Dis 2011;52(3):285-292. doi: https://doi.org/10.1093/cid/cir034.

21. Gordon CL, Thompson C, Carapetis JR, Turnidge J, Kilburn C, Currie BJ, Trough concentrations of vancomycin: adult therapeutic targets are not appropriate for children. Pediatr Infect Dis J. 2012;31(12):1269-71. https:// doi.org/10.1097/INF.0b013e31826a3eaf.

22. Madigan T, Sieve RM, Graner KK, Banerjee R. The effect of age and weight on vancomycin serum trough concentrations in pediatric patients. Pharmacotherapy. 2013;33(12):1264-72. https://doi.org/10.1002/phar.1331.

23. Hoang J, Dersch-Mills D, Bresee L, Kraft T, Vanderkooi OG. Achieving therapeutic vancomycin levels in pediatric patients. Can J Hosp Pharm. 2014:67(6):416-22.

24. McCabe T, Davis G, locono J, Nelson C, Kuhn R. Evaluating the empiric dose of vancomycin in pediatric patients [abstract]. In: 18th annual meeting abstracts. J Pediatr Pharmacol Ther. 2009;14(3):167-8. https://doi.org/10. 5863/1551-6776-14.3.154

25. Blot SI, Pea F, Lipman J. The effect of pathophysiology on pharmacokinetics in the critically ill patient--concepts appraised by the example of antimicrobial agents. Adv Drug Deliv Rev. 2014;77:3-11. https://doi.org/10. 1016/j.addr.2014.07.006.

26. Katip W, Jaruratanasirikul S, Pattharachayakul S, Wongpoowarak W, Jitsurong A, Lucksiri A. The pharmacokinetics of vancomycin during the initial loading dose in patients with septic shock. Infect Drug Resist. 2016;9:253-60. https:// doi.org/10.2147/IDR.S121513.

27. Vazquez M, Fagiolino P, Boronat A, Buroni M, Maldonado C. Therapeutic drug monitoring of vancomycin in severe sepsis and septic shock. Int J Clin Pharmacol Ther. 2008:46(3):140-5.

28. Barbour A, Scaglione F, Derendorf H. Class-dependent relevance of tissue distribution in the interpretation of anti-infective pharmacokinetic/ pharmacodynamic indices. Int J Antimicrob Agents. 2010;35(5):431-8. https://doi.org/10.1016/j.jiantimicag.2010.01.023.

29. Scaglione F. Pharmacokinetic/pharmacodynamic (PK/PD) considerations in the management of gram-positive bacteraemia. Int J Antimicrob Agents. 2010;36(Suppl 2):S33-9. https://doi.org/10.1016/j.jjantimicag.2010.11.011.

\section{Publisher's Note}

Springer Nature remains neutral with regard to jurisdictional claims in published maps and institutional affiliations.

Ready to submit your research? Choose BMC and benefit from:

- fast, convenient online submission

- thorough peer review by experienced researchers in your field

- rapid publication on acceptance

- support for research data, including large and complex data types

- gold Open Access which fosters wider collaboration and increased citations

- maximum visibility for your research: over $100 \mathrm{M}$ website views per year

At $\mathrm{BMC}$, research is always in progress.

Learn more biomedcentral.com/submissions 